\title{
THE ISSUE OF CHURCH AND STATE AT VATICAN COUNCIL II
}

JOHN COURTNEY MURRAY, S.J.

\author{
Woodstock College
}

No fORMal document on the relations between Church and state issued from Vatican Council II, although the issue had appeared in the legislative history of the Council. The original schema of the Constitution on the Church, distributed on November 10, 1962, contained a chapter (9) "On the Relations of Church and State." It was a revision of a prior text, also written by the Theological Commission, "On the Relations of Church and State and on Civil Tolerance." Also during the preconciliar period-in December, 1960-a schema on religious freedom was prepared by a subcommission of the Secretariat for Promoting Christian Unity, meeting in Fribourg. It was recognized that the particular issue of religious freedom needed to be clarified, if there was to be any hope of instituting proper ecumenical relationships between the Catholic Church and the other Christian churches and communities.

In June, 1962, Cardinal Bea presented to the Central Commission a revision of the Fribourg schema, containing three brief chapters, the third of which was entitled "On the Relations between the Church and Civil Society." At the same time the Theological Commission presented its own schema-the first of the two mentioned above. A lengthy discussion of the two schemata proved inconclusive; their respective tendencies were quite diverse. The matter was referred to Pope John XXIII, who created in July, 1962, a mixed committee whose function would be to effect a reconciliation of the two tendencies. (In the end, this committee - composed of Cardinals Ciriaci, Ottaviani, and Bea, Msgr. Willebrands, and Fr. Tromp-never met.) In that same month the Secretariat schema was revised, to take account of certain views expressed in the schema of the Theological Commission. In February, 1963, the Secretariat decided further to revise its schema and to leave aside the Church-state issue. This new revision, approved by the Secretariat in May, 1963, was presented to the Co-ordinating Commission in July, and the decision was reached that it should be 
chapter 5 of the schema on ecumenism to be presented by the Secretariat. (The details of the long delay in getting the text printed need not concern us here.) Chapter 9 was omitted from the revised schema on the Church. And thus it came about that only the issue of religious freedom was discussed by the Council.

The explicit intention of the Declaration on Religious Freedom was narrowly defined in the final text, namely, "to develop the doctrine of recent popes on the inviolable rights of the human person and on the constitutional order of society" (n. 1). Nevertheless, in the course of fulfilling this relatively restricted doctrinal intention, the Declaration made certain significant contributions towards a development of doctrine in regard to the Church-state issue. In its turn, the Constitution on the Church in the World Today confirmed, and in certain respects advanced, this development. The purpose of this article is to analyze the development.

\section{THE NEW PROBLEMATIC}

In general, the development consisted in a transformation of the state of the question. A movement in a new direction had already been begun by Leo XIII. From early Christian times, through the medieval era, through the later era of the French classical monarchy, and through the post-Reformation epoch of confessional absolutism, the primary issue had been stated in terms of the relationship between the two powers, spiritual and temporal-pope and emperor, pope and king or prince. This issue retained a mode of its validity for Leo XIII. He did not indeed contend for "union of Church and state" on the model of the ancien régime, wherein the Union of Throne and Altar entailed an enclosure of the national Church within the national kingdom and some consequent manner of subordination of Church to state. However, against the dogma of "separation of Church and state" in the sense of Continental laicism, he consistently contended for an orderly relationship between ecclesiastical and political authority. At the same time he transformed this ancient issue of the dyarchy by including it within a broader statement of the question, to which the conditions of the time-the progressive laicization and also industrialization of society in Continental Europe-led him.

The new terms were the "Church," both as a spiritual authority and 
also as the community of the Christian faithful, and "human society" in the whole range of its institutional life - social, economic, and cultural, as well as political. Within this broader context, the issue of the dyarchy tended to appear, less as a formally juridical issue of structural relationships between the two powers, than as the wider issue of their reciprocal co-operation toward the integral good of the "same one man, both Christian and citizen," whom they both encounter-and thus encounter each other-in the concrete life of society. What supremely mattered to Leo XIII was the establishment of a Christian order in the whole of society. The orderly relationship between the two powers was simply a subordinate aspect of this larger goal. The issue of the dyarchy as such had begun to lose its ancient primacy.

Vatican Council II pursued and prolonged this line of development. The chief witness here is the whole Constitution on the Church in the World Today. Of particular significance are Part 1, chapter 3, "On Human Activity in the Whole World," and chapter 4, "On the Function of the Church in the World Today." The basically Leonine inspiration of these two chapters is instantly visible; but so too is the development of doctrine beyond its Leonine stage. And again the source of the development lies in a broadening of the perspectives in which the question is viewed.

For Leo XIII, "human society" meant concretely the Europe of the nineteenth century. His religious interests did indeed range much farther afield. But the focus of his political and social teaching, as of his diplomacy, was obviously on the European nations, chiefly the socalled Catholic nations, as these underwent the shattering impact of the French Revolution, Continental laicism, and the Industrial Revolution. In contrast, for Vatican II, "human society" meant quite literally the whole world - and the whole world as it is everywhere undergoing the more shattering impact of the technological revolution of the twentieth century.

Again, both Leo XIII and Vatican II were concerned with religion as the basic dynamic element-both salvific and civilizational-in the life of the world, whether in the broader or in the narrower sense of the term "world." For Leo XIII, however, religion uniformly meant Christianity and Christianity uniformly meant the Catholic Church, which he conceived to be not only the unique but also the exclusive ecclesial 
form of Christianity. The Christian religion in this Catholic sense was for him the "teacher and nurse of Christian civilization," that is, the civilization of Europe. (He also firmly supported the religio-political privileges of France with regard to missionary activity in the East and Far East, which dated from the days of Francis I, and which resulted, in effect, in the identification of Catholic expansion and the expansion of French national culture- a result not altogether happy in its confusion of Christianization and Europeanization.) In particular, the Christian religion in its Catholic sense was, for Leo XIII, the origin and support of the unity of the Catholic European peoples. In so far as he paid attention to the religion and to the ecclesial communities which emerged from the Reformation, it was to regard them as representing, not only religious error, but also a solvent of traditional European culture. (Be it noted, on the other hand, that he was the first Pope to use the phrase "separated brethren."1)

In this sense his religio-civilizational outlook was related to his historical outlook, which was simple and narrow. The key to it is in the famous once-upon-a-time passage ("Fuit aliquando tempus....") in Immortale Dei. ${ }^{2}$ The medieval era was the golden age of Christian unity, of harmony between the two powers, and of the obedience of princes and peoples to the authority of the Church. Then came the Reformation, which was a revolt against the authority of the Church, the rupture of Christian unity, and the origin of profound civilizational change. Later, by virtue of logical as well as historical sequence, came the Revolution, which was a revolt against the sovereignty of God Himself, a schism within the Catholic nations, a disruption of the relationship between the two powers, and the beginnings of the laicization of European culture. Within these historical perspectives, whose focus of origin was in the past, Leo XIII could not but call for a return to a Christian unity once possessed, to an ecclesiastical obedience once rendered, to the matrix of a culture once fertile of Christian forms.

Vatican II, however, relinquished this retrospective view of history and adopted a prospective view. Its perspectives open out from the

${ }^{1}$ Lettre à Mgr. Satolli à propos du Congrès des Religions, 8 septembre 1895 (Lettres Apostoliques de S. S. Lion XIII, Texte latin avec la traduction française en regard [Paris: Maison de la Bonne Presse, n.d.] 257). This edition is hereafter cited as "Bonne Presse," with volume and page.

${ }^{2}$ Bonne Presse 2, 32. 
present. They are set by the signs of the times, which are chiefly two. The first is a rising consciousness of the dignity of the human person; correlative with it is a mounting movement toward the unity of the human family. Therefore the problem for the Church, as for man himself, is an increasing realization, in all manner of institutional forms, both of human dignity and of human unity. "As we undertake our work therefore," said the Council in its Message to Humanity on October 20,1962, "we would emphasize whatever concerns the dignity of man, whatever contributes to a genuine community of peoples." Hence the work of the Church, as the work of man himself, looks to the future. It implies a movement forward-not a return but a renewal.

Moreover, the doctrinal perspectives of Vatican II are ecumenical, whereas Leo XIII's were not. Not only did the Council gratefully acknowledge the "heritage of faith handed down by the apostles" as found in the Eastern Churches, and the Christian and ecclesial elements retained in the separated churches and ecclesial communities in the West, and the religious values in non-Christian religions, and in particular the community of tradition between Christianity and Judaism. In the same spirit it also recognized that the future of civilization on this earth depends, not solely on the Church, but on the widest possible co-operative effort. The Council reiterated the Leonine position, as in this text from the Constitution on the Church in the World Today: "The Church believes that she, through each of her members and through the entirety of her community, can contribute greatly toward making the family of men and its history more human" (n. 40). But there is a new development: "In addition, the Church gladly sets a high value on the contributions which other Christian churches and ecclesial communities have made and are making, in a united effort, toward the fulfilment of the same task" (loc. cit.). Leo XIII never said that. Nor did he rise to the humility of the further statement: "At the same time, [the Church] holds firmly that she can be assisted to a great extent and in a variety of ways by the world itself, by individual men and by human society, through their endowments and efforts, in preparing the way for the gospel" (loc. cit.).

Continuity, however, is here visible. Leo XIII took the first decisive step toward healing the breach between the Church and the European world of his day, which had been his unhappy legacy from the pon- 
tificate of Pius IX. He offered to this limited "world" the assistance of the Church for the healing of the ills of the time. Vatican II took a much longer step in the same direction. It repeated Leo's offer-on a more generous scale - and thus reaffirmed an ancient tradition. It also did something new. In its turn it asked the world-conceived in all its global sweep and growing complexity - for its own assistance, not merely for the healing of the ills of the times (upon which, in the spirit of John XXIII, the Council did not lengthily dwell), but more importantly for the fulfilment of the signs of the times. The Council repeatedly insisted that the inherent sense of the gospel summons the Church to the task of lifting man to his true dignity and of knitting the bonds of human community. It also insisted that the world must know itself to be summoned to the same task by the stirrings within its own consciousness.

It is not the intention of this essay to pursue in detail, or to estimate the adequacy of, the Council's solution to its own developed version of the Leonine problematic. The first point here is the new conception of the problematic. Its terms are not now, as they were for Leo XIII, the Catholic Church and human society in Europe. The terms are widerreligion in its full ecumenical sense and human society throughout the wide world. The second point is that, again in continuity with Leo XIII, the Council situated the narrow issue of Church and state within the context of its own widened problematic. Thus it effected a further transformation of the state of the narrower question. And in consequence it opened the way to a development of doctrine on the matter. It can hardly be said that the Council itself wrought out the development. Nevertheless, it offered certain guidelines. They may be gathered both from the Declaration on Religious Freedom and from the Constitution on the Church in the World Today.

\section{DIGNITATIS HUMANAE}

In the first place, in accordance with the world-wide outlook of the Council, the Declaration acknowledges the fact of the religiously pluralist society as the necessary historical context of the whole discussion. The acknowledgment is implicit in the intention of the document to deal with a universal human right. It becomes more explicit in the section on corporate religious freedom (n. 4) and in the concluding 
pastoral exhortation (nn. 14-15). Leo XIII, in contrast, by reason of his restricted and retrospective view of history, had tended to assume, as the historical premise of the Church-state question, the religious unity of the Catholic nations, so called, and the historic rights acquired by the Church within this limited geographical context. His thought was still, in a sense, tributary to the view, developed largely in the postReformation era and accepted then by both Catholic and Protestant rulers and by their respective churches, that the introduction of religious pluralism into a religiously unitary society was illegitimate; that it was to be resisted by the power of government; that government could do no more than tolerate it, and then only when religious dissent had so established itself as a social force that the attempt to eradicate it by force would do more harm than good.

In the second place, the Declaration embraces the political doctrine of Pius XII on the juridical state (as it is called in Continental idiom), that is, on government as constitutional and as limited in functionits primary function being juridical, namely, the protection and promotion of the rights of man and the facilitation of the performance of man's native duties. The primacy of this function is based on Pius XII's personalist conception of society - on the premise that the "human person is the foundation, the goal, and the bearer of the whole social process," ${ }_{3}$ including the processes of government. In contrast, Leo XIII had held a more statist and moralist view of society. In his classic encyclicals, up to Rerum novarum, the traditional distinction between society and state is obscured; the foundation and bearer of the social process is the ruler (or, if you will, the state); and the goal of the ruler-state is the common good considered as an ensemble of virtues in the body politic, notably the virtue of obedience to rule. It is not until Rerum novarum that the dignity of the human person and the inviolability of his rights begins to emerge as determinant of social and political doctrine, thus affording the point of departure for the doctrine of Pius XII, John XXIII, and the Council.

In the present matter, the significance of the political doctrine of the Declaration (as also of the Constitution on the Church in the World Today) lies in its disavowal of the long-standing view of government as sacral in function, that is, as invested with the function of defending

'Cited by John XXIII in Pacem in terris (AAS 55 [1963] 263) from Pius XII's Radio Message, Christmas, 1944. 
and promoting religious truth as such. This view of government is visible even in Leo XIII. Its disavowal by the Declaration follows on its intention to develop the doctrine of more recent popes on the constitutional order of society. In this development the function of government appears as the protection and promotion, not of religious truth, but of religious freedom as a fundamental right of the human person. This is a secular function, since freedom in society-notably religious freedom - is a secular value, as are the values of justice and love or civic friendship. All three of these values are rooted in the truth about the human person, which is the truth upon which the whole social and political order rests. Hence the tutelage of these values is proper to the notion of government as secular in the full range of its purposes. It is true that the final text of the Declaration is inadequate in its treatment of the limitations imposed on government by sound political doctrine. Nevertheless, the disavowal of the old notion of government as sacral in function is sufficiently clear, both from the firm statement of the essentially juridical function of government (n. 6), and also from the earlier statement that the proper purpose of government is to have a care for the common temporal good and that it would exceed its limits were it to presume to direct or impede religious acts (n. 3). These statements, jejune though they are, exclude the notion that government is to be the judge of religious truth, the defender of the true faith, or the guardian of religious unity.

In the third place, in systematic harmony with its own doctrine on the universal right to religious freedom and on the limitations of governmental power in matters religious, the Declaration makes the statement: "The freedom of the Church is the fundamental principle in what concerns the relations between the Church and governments and the whole civil order" (n. 13). The import of this statement is considerable. It opens the way to a new structure of Catholic doctrine on Church and state - to a renewal of the tradition whose great exponent was Gregory VII: "In moments of considered solemnity, when their tone was passionate and their religious feeling at its deepest, Gregory VII and his contemporaries called the object toward which they were striving the "freedom of the Church." ", In modern times Leo XIII powerfully effected a renewal of the Gregorian tradition: "A major

'G. Tellenbach, Church, State and Christian Society at the Time of the Investiture Contest (tr. R. F. Bennett; Oxford: Blackwell, 1940) p. 126. 
significance of Leo XIII in the history of doctrinal development lies in his great effort to rescue the Church from the regalist tradition-from that servitude to the state under which it had lain for nearly half a millennium of regalism. The servitude dated from the triumph of Philip the Fair's lawyers over Boniface VIII, which had been solidified by the rising centralized monarchies, especially in France. In a full view, Leo XIII appears as the Gregory VII of the nineteenth century, returning under the stress of the times [as regalism reappeared in laicist garb] to the splendid device under which the great Hildebrand fought his battle, 'the freedom of the Church." ", The phrase occurs in well over a hundred texts in the Leonine corpus, of which perhaps one fourth have to do with the Roman question. One providential result of this tragic impasse was that it drew the attention of the papacy to the "fundamental principle."

The implications of the principle were not worked out in the postLeonine canonist systematizations. Oddly enough, the inarticulate major premise controlling these systematizations seems to have been the civilist formula, the "unity of the Church." In the late medieval view of the civilists the formula stressed the role of the prince in the construction of the ecclesia, that is, christianitas, the Christian world. The role of the prince, now understood as the "Catholic state," in the construction of the Christian society, now contracted to the dimensions of the "Catholic nation," seems likewise to have been a major preoccupation of the modern canonists. The text of Dignitatis humanae, however, made vital contact with the profound doctrine of Leo XIII, and through him with the genuine tradition.

After the vote on the fifth conciliar schema (textus recognitus, which was presented on October 25, 1965), an amendment was submitted by three Fathers, suggesting that in n. 13 the text should read "fundamental condition" instead of "fundamental principle," in referring to the freedom of the Church. The reasons for the change were not given. At any rate, the substitute text would have been in harmony with the received opinion in the canonist school, according to which the freedom of the Church is merely the fundamental condition of right relationships between Church and state, whereas the fundamental prin-

5John Courtney Murray, S.J., "Leo XIII: Separation of Church and State," TrezoLOGICAL STUDIES 14 (1953) 192. 
ciple is the Church's exclusive right to a situation of legal privilege. The amendment was rejected. The laconic reason advanced by the Secretariat read: "It is a question of a true principle." The response was not wholly adequate.

The text of the schema was, in fact, an implicit citation from the Encyclical Letter of Leo XIII to the French Cardinals, Notre consolation (May 3, 1892). In it he defends himself against the charge that his policy of ralliement in France was inconsistent with the policy of opposition that he was adopting toward the government of Italy-the former policy being religious in inspiration; the latter, political. The policies, he replies, are profoundly consistent, since "the question which concerns us in Italy is also eminently religious in as much as it is related to the fundamental principle of the freedom of the Church," which was also the principle at stake in France. The freedom of the Church is not merely a true principle; it is the fundamental principle governing the relations of the Church with all governments.

This is not the place to explain in detail what the formula "the freedom of the Church" meant to Gregory VII within the context of medieval Christendom. The Vatican Declaration, however, gives an adequate explanation of what the freedom of the Church concretely means today. In an implicit citation from Pius XII it is said to mean "that stable condition of right and of fact [which guarantees] the necessary independence [of the Church] in the fulfilment of her divine mission" (n. 13). Moreover, a proper distinction is made between the Church as an authority and as a community. And in both senses the Church claims freedom as a strict right. In the sense of the Declaration the object or content of the right is negative - an immunity from coercive constraint or restraint by any human power in society or state, whether in the exercise of spiritual authority or in the communal living of the Christian life.

It should be noted here that the freedom of the Church is understood in this same sense in Christus dominus, the Decree on the Pastoral Office of Bishops: "In the performance of their apostolic office, which looks to the salvation of souls, bishops per se possess full and perfect freedom and independence of any civil power. Wherefore it is not permissible to impede, directly or indirectly, the exercise of their eccle-

'Lettre encyclique aux Cardinaux Français, 3 mai 1892 (Bonne Presse 3, 127). 
siastical office or to prohibit their free communication with the Apostolic See, with other ecclesiastical authorities, and with their subjects" (n. 19). Here the freedom of the Church as a spiritual authority is presented as an immunity. This concept, here as in Dignitatis humanae, is technically correct.

A more detailed description of the meaning of the freedom of the Church is given in the section of the Declaration which deals with religious freedom as a corporate right. This section was written with a view to satisfying the requirements both of the freedom of the Catholic Church (as set forth, for instance, in Leo XIII) and also of the freedom of the churches and ecclesial communities (as set forth in the declarations of the World Council of Churches, notably at Amsterdam in 1948 and at New Delhi in 1961). Two general areas of freedom are distinguished. The first includes the internal affairs of the community-its organization, manner of rule, worship, religious nurture, the selection, training, appointment, and transferral of ministers, communications ad extra, the erection of churches, the possession of property. The second includes the external action of the community-its public witness to its own faith as such, and its further witness to the values of its faith in their relation to the affairs of the temporal order. The Declaration makes no concessions to an "angelist" conception of religion or to the notion of churches as being shut up "in the sacristy."

Furthermore, the Declaration makes sufficiently clear-without being altogether as precise as might be desired - that the foundation of the Catholic Church's right to freedom is twofold. The theological foundation is the mandate of Christ to preach His gospel and to observe His commandments (n. 13). This unique theological title, however, cannot be urged in political society and against government. The mandate of Christ to His Church is formally a truth of the transcendent order in which the authority of the Church is exercised and her life as a community is lived. Therefore it is not subject, or even accessible, to judgment by secular powers as regards its truth or falsity. The authorities and faithful of the Church are indeed conscious that their freedom is of divine origin - a participation respectively in the freedom of the Incarnate Word and in the freedom of the Holy Spirit. In political society, however, and in the face of government, only that title to freedom may be urged which the powers of the secular order are able, and 
are obliged, to recognize. This title is the basic truth about the dignity of the human person and about the necessary freedom of his lifeespecially his religious life, both personal and corporate - in society.

This distinction between the Church's two different titles to freedom is of the highest importance. If the unique theological title is not asserted, the way is opened to indifferentism-the reduction of the Catholic Church to one of many ecclesial communities, whose respective rights to freedom rest on univocally the same foundation, namely, a divine mandate. On the other hand, if the theological title is asserted against secular powers in society and state, the way is opened to a confusion of the two orders of human life - to a negation of the transcendence of the Church and to a violation of the due autonomy of the secular order, as this autonomy was defined by the Council rather more sharply than ever before (a matter to be dealt with later).

The Church would abdicate her transcendence, were she to present her theological title to freedom in society for judgment by any organs of secular government. As has been said, the Declaration itself makes sufficiently clear that secular government today-given the developed differentiation of the secular and sacral orders - is not empowered to make judgments de meritis in matters of theological truth. At the same time, the due autonomy of the secular order would be violated, since this autonomy requires that the powers which rule the secular order should make judgments on the secular grounds proper to that orderthe truth which is its foundation, the justice which is its goal, the love or civic friendship which is its motivating and unifying force, the freedom which is at once its goal and its method of pursuing the goal of justice. Hence the autonomy of the secular order requires that, within this order and in the face of its constituted organs of government, the Church should present her claim to freedom on these secular groundsin the name of the human person, who is the foundation, the end, and the bearer of the whole social process.

It should be noted too that the distinction here in question is of the highest ecumenical importance. On the one hand, it establishes the churches and ecclesial communities on a basis of reciprocity, both with regard to the object or content of their right to freedom in the social and political order, and also with regard to the foundation of this right as asserted within this order. On the other hand, this reciprocity, pre- 
cisely because it is an affair only of the political and social order, implies no blurring or leveling of the doctrinal differences among the churches, which are of quite another order. As the Decree on Ecumenism says, and as all convinced Christian believers agree: "Nothing is so foreign to the spirit of ecumenism as a false irenicism which harms the purity of Catholic doctrine and obscures its assured genuine meaning" (n. 11). At the same time, the rules of the dialogue must be such that "each can treat with the other on a footing of equality" (n. 9). This reciprocity in the ecumenical dialogue is a matter of love and respect, not only for the other as a person, but also for the truth as possessed by each, to be understood by both. An analogy is visible here. The civil community in its most profound meaning and manner of action is itself a form of dialogue. The dialogue does not disguise, but brings to light, differences of view. But in order that it may be a proper dialogue, it is essential that each should treat with the other on a footing of equality. In the civil dialogue, which is carried on under conditions of constitutional order, this reciprocity is a matter of strict right. And the constitutional right - in our case, to equal religious freedom -is the necessary condition and firm support of the ecumenical dialogue.

A certain uneasiness or discontent was felt by some of the conciliar Fathers and theologians over the "negative" notion of religious freedom put forward by the Declaration. They would have wished it to be said that the freedom of the Church is a "positive" freedom. But surely there is here some failure to make the necessary distinction between two orders of discourse and reality.

The mandate of Christ empowers the Church to preach the gospel to every creature - to every man as a creature of God, to whom the divine message of salvation is addressed. To this empowerment or freedom of the Church there corresponds on the part of all men and all peoples an obligation to hear the word of God and to respond to it by faith as assent and consent. In this sense the content of the freedom of the Church is positive; it is a freedom "for" the preaching of the gospel. This discourse, however, moves in the transtemporal order of the history of salvation-the order of man's vertical relation, so to speak, to God acting and speaking in history through His Church. On the other hand, the technical issue of religious freedom rises in the juridical order, which is the order of horizontal interpersonal relations 
among men, between a man and organized society, and especially between the people - as individuals and as associated in communities, including religious communities - and the powers of government. As asserted in the interpersonal order of human rights, the freedom of the Church, whether as a community or as an authority, is and can only be negative in its content; it is a freedom "from" any manner of coercive constraint imposed by any secular power. As further guaranteed in the constitutional order of civil rights, the freedom of the Church consequently appears as an immunity. To confuse these two distinct orders of discourse, and the modes of freedom proper to each, is to run into inextricable difficulties.

One may be mentioned. Government is a power whose mode of action, like that of law, is ultimately coercive. If the freedom of the Church in the juridical order is rightly taken to be no more than an assurance against the use of governmental power, or any other secular power, in restraint of her divine mission, no difficulty arises. On the contrary, this self-denying ordinance on the part of government is a matter of obligation. This is obvious. On the other hand, if the freedom of the Church in the juridical order is taken to be some manner of positive claim on government, the claim can only be that government should use its power in furtherance of the Church's divine mission. Quod absit. No other positive content to the claim can be assigned. The Church cannot ask governments, as she asks men, for faith in the word of God. What she asks - all she can ask - of governments was immortally stated by Paul VI, in fidelity to the tradition and in authentic confirmation of the doctrine of Dignitatis humanae, when he spoke to statesmen in his discourse of December 8, 1965: "And what is it that the Church asks of you, after almost two thousand years of all manner of vicissitudes in her relations with you, the powers of earth-what is it that she asks of you today? In one of the major texts of the Council she has told you what it is. She asks of you nothing but freedomfreedom to believe and to preach her faith, freedom to love God and to serve Him, freedom to live and to bring to men her message of life."

It is clear therefore that the Council renewed traditional doctrine on the relations of Church and state by restoring, in continuity with Leo XIII, the principle of the freedom of the Church to its fundamental

'AAS 58 (1966) 10-11. 
place in the structure of the doctrine. By the same token, it is clear that the issue may no longer be argued in terms of "union" and "separation" of Church and state, or in terms of "thesis" and "hypothesis." The words "union" and "separation" can mean, and in the course of history have meant, many things. In the modern canonist school, however, union of Church and state has at least meant the legal establishment of Catholicism as the religion of the state, to which constitutional status certain privileges normally accrue, and from which, in the case of other cults, certain civil disabilities logically follow. ${ }^{8}$ Union in this sense is the thesis, the ideal prescribed by Catholic doctrine. In turn, separation, which means at least a constitutional situation of nonestablishment and of equal religious freedom for all, is hypothesis, a concession to circumstances, to be no more than tolerated. ${ }^{9}$

In the legislative history of the Declaration the issue of establishment was first mentioned in the Relatio de animadversionibus Palrum which was included in the fascicle with the third conciliar schema (textus emendatus) presented in November, 1964. There it was said:

The institution of religious freedom prohibits such legal intolerance as would reduce certain citizens or certain religious communities to a condition of inferiority in what concerns their civil rights in matters religious. But it does not forbid that the Catholic religion should be recognized by human law as the common religion of the citizens in a particular country -in other words, that the Catholic religion should be established by public law as the religion of the state. In such a case, however, care must be taken that from the institution of a state-religion no juridical or social consequences should be derived that would infringe the equality before public law of all citizens in religious matters. In a word, together with the institution of a state-religion the institution of religious freedom is to be maintained.

The purpose of this note was to respond to the objection of some Fathers that a declaration of general religious freedom would be at odds with the institution of establishment as approved by the Church, in practice and-according to some-by doctrine.

${ }^{8}$ Pius XI, Letter to Card. Gasparri, May 30, 1929, on the Lateran Pacts, in J. B. Lo Grasso, S.J., Ecclesia et status: De mutuis officiis et iuribus fontes selecti (Rome: Gregorian University, 1939) pp. 326-27: “. . . la Religione cattolica è, e sol'essa, secondo lo Statuto ed i Trattati, la Religione dello Stato con le logiche e giuridiche conseguenze di una tale situazione di diritto costitutivo ...," that is, other cults are only "tollerati, permessi, ammessi."

${ }^{9}$ This is the position stated in somewhat softened form in chapter 9 of the original schema of the Constitution on the Church, which emanated from the Theological Commission in November, 1962. 
In response to the wishes of some Fathers, a sentence on establishment was inserted in the text of the fourth conciliar schema (textus reemendatus) presented in September, 1965. It read: "The institution of religious freedom does not stand in the way of special recognition being given to one religious community in the constitutional order of a society, under consideration of historical circumstances among peoples, in such wise, however, that at the same time the right of all citizens and religious communities to religious freedom be acknowledged and maintained."

This statement proved controversial. The Relatio of the Secretariat on the changes made in the fifth conciliar schema (lextus recognitus) presented in October, 1965, distinguished four positions: (1) that no mention of establishment be made; (2) that the text should clearly affirm that special constitutional recognition must be given to the true religion whenever this is possible; (3) that, if the Declaration deals with establishment, it should do so in a conditional sentence; (4) that the Declaration should deal with establishment but in a conditional sentence. The Secretariat voted to accept the fourth proposal as the via media. Hence the fifth schema was made to read thus: "If, under consideration of historical circumstances among peoples, special civil recognition is given to one religious community in the constitutional order of a society, it is necessary at the same time that the right of all citizens and religious communities to religious freedom should be acknowledged and maintained" (n. 6).

After the vote of October 26, 1965, some sixteen modi dealing with this sentence were submitted. One of them, signed by three Fathers, asked that the whole sentence be stricken out. Another, signed by twenty-eight Fathers, asked that the sentence be changed from its conditional form back to its former declarative form. The rest proposed merely verbal alterations. The two significant changes were rejected by the Secretariat on grounds of the overwhelming vote of approval given to the section in question (2,034 to 186). Hence the final text retains the conditional form.

It is therefore clearly the mind of the Council that the establishment of Catholicism as the religion of the state is no more than a matter of historical circumstances, and not a matter-or even a consequence - of doctrine. It is not thesis but hypothesis. In fact, the conditional form 
of the conciliar statement, taken in its full force and in the light of the interventions of the Fathers who recommended it, reveals the unwillingness of the Council to approve the institution of establishment even as a matter of purely historic right. On the other hand, it is even more clearly the mind of the Council that the institution of religious freedom is not hypothesis but thesis - a matter of doctrine, not of historical circumstances. To put the whole thing more simply, it is time now to drop the categories of thesis and hypothesis completely out of the Catholic vocabulary. The future systematization of Catholic doctrine on Church and state will not have the disjunctive structure characteristic of the once-received opinion. Its structure will be unitary.

Moreover, it will have to be more than a doctrine on "Church and state" in the theological sense of "Church" and in the classical sense of "state." The traditional rubric accurately defined the issue only in the days when the Church was, or was considered to be, conterminous with society, and when a single structure of spiritual authority confronted a single structure of temporal authority. The Council, by its recognition of religious pluralism in the world (in the conciliar sense of "world"), acknowledged that this historical situation no longer exists, if it ever really did exist. The same acknowledgment is implicit also in the very notion of the "pilgrim Church," which was a dominant conciliar theme. The traditional rubric may still be useful to designate the contemporary issue, if its terms are invested with a symbolic meaning and used to designate the poles of that permanent tension in human society which reflects the tension inherent in the dual nature of man, who is a creature both of time and of eternity. However, after Dignitatis humanae and Gaudium et spes, the literal terms of the issue are rather "religion and government," religion in a historical-pluralist sense, and government in the constitutional sense accepted by these two conciliar documents, following Pacem in terris. This narrow issue, moreover, exists at the interior of, and in subordination to, the larger problematic of "religion and human society," already described.

The relationship of religion and government was regarded by Dignitatis humanae both as a theological-religious issue and also as a constitutional and legal issue. And the relationship was primarily defined in terms of freedom - the freedom of the human person and the freedom of 
religious communities, including the Church. The Declaration, in effect, affirmed the independence of "Church" and "state." But the notion of independence does not exhaust the issue of the relationship between these two social magnitudes, which are also structures of authority (in diverse ways, of course). Does their independence imply their separation-and what is the meaning of "separation"? Does it imply the neutrality of government toward religion, and what kind of "neutrality"- a neutrality of indifference or of general benevolence? Does it imply reciprocal co-operation and mutual support-and to what estent and in what forms? These are complex questions, and the Declaration did not undertake to deal with them adequately.

There was, however, among some of the Fathers a fear that the Declaration might be interpreted in the separationist sense of Continental laicism, which implied either hostility or at best indifference toward religion on the part of government. There was little, if any, basis for this fear, unless the concept of religious freedom in the Declaration were to be egregiously misunderstood. At any rate, in order to preclude the possibility of misinterpretation, a half sentence was added in the sixth and final conciliar schema: "Government, whose proper function is to care for the common temporal good, ought indeed to recognize the religious life of its citizens and to favor it ..." (n. 3). Later, moreover, when it is a question of the duties of government, two are noted. The primary duty is toward the religious freedom of all citizens. The second duty is "to supply conditions favorable to the cultivation of religious life, in such wise that citizens may in fact be enabled to exercise their religious rights and to discharge their religious duties, and that society itself may enjoy the values of justice and peace which ensue upon the fidelity of men toward God and His holy will" (n. 6).

It must be admitted that this second duty is not phrased with entirely luminous clarity. Nevertheless, the intention of the statement is clear enough. It is primarily negative, that is, it is meant to exclude either a hostile or an indifferent attitude toward religion on the part of government. However, the positive meaning of the statement was deliberately left vague. What do governmental "recognition" and "favor" of religion in society concretely mean? In particular, what 
manner of constitutional or statutory transcription of such recognition and favor should be made? Again, what is concretely meant by "conditions favorable to religious life"? The text leaves these concrete questions open, because the answer to them would largely depend on variant circumstances.

The positive intention, however, is not in doubt. It was to affirm the traditional doctrine that religion is a social good, a fundamental element of the common temporal good of society. This was the doctrine upon which Leo XIII endlessly insisted. Religion is not simply an affair of the internal forum of conscience or even of the sacristy. It is formally a matter of public interest. Consequently it claims the recognition and the favorable attention of government. Leo XIII was speaking, of course, about the Catholic religion, in the face of the laicizing governments of Continental Europe. The Declaration develops his doctrine by clearly stating that governmental recognition and favor of religion in society are to be accorded under safeguard of the principles of religious freedom and of the equality of all citizens before the law-an equality which "itself is integral to the common good of society" (n. 6). Therefore not only are hostility and indifference excluded; so too is "discrimination" on religious grounds (n. 6). This latter exclusion was necessary in order that the Declaration might be faithful to the Pian and Johannine (not Leonine) notion of the common good-that its primary component is juridical.

For the rest, it would seem to be in the sense of the Declaration to say that governmental favor of religion formally means favor of the freedom of religion. Similarly, conditions favorable to religious life should be understood to mean conditions favorable to the free profession and practice of religion. Government does not stand in the service of religious truth, as an instrument for its defense or propagation. Government, however, must somehow stand in the service of religion, as an indispensable element of the common temporal good. This duty of service is discharged by service rendered to the freedom of religion in society. It is religion itself, not government, which has the function of making society religious. The conditions favorable to the fulfilment of this function are conditions of freedom. In the way of sheer principle, it seems not possible to say more than this. And this much the Declaration says. 


\section{GAUDIUM ET SPES}

The Constitution on the Church in the World Today reveals a sharper sense of the distinction between society and state than can be found in Leo XIII, or perhaps even in Pius XII, though the latter, in virtue of his concern for the juridical order of society, began to sort out the confusions visible in the former. The Constitution deals with our question roughly in terms of this distinction. In Part 1, chapter 4, there is question of the relation of the Church to human society and of her function in human society. In Part 2, chapter 4, the narrower question comes up, "Church and state." In neither case is the treatment systematic; but some important principles are stated.

In dealing with the Church-and-society problematic, two major concerns seem to pervade the Constitution. One is to reaffirm the Leonine distinction between the two societies and likewise to reaffirm the transcendence of the Church to the temporal order. The mission of the Church, it is said, "is not of the political, economic, or social order; the purpose which [Christ] set for it is of the religious order" (n. 42). In consequence, the Church "is not bound to any particular form of human culture, or to any political, economic, or social system" (loc. cit.). In further consequence, her ardent wish is "that, standing in the service of the good of all, she may be able to develop freely under any form of government which recognizes the fundamental rights of the person and of the family, and also recognizes the exigencies of the common good" (loc. cit.).

The statement adds a new breadth and an important qualification to Leo XIII's oft-repeated thesis of the indifference of the Church to political forms. Leo XIII, in the face of the French Catholic Right, was endeavoring to disentangle the Church from the institution of monarchy, without at the same time committing the Church to democratic institutions, about which he knew nothing, except in so far as these institutions appeared, in vitiated and unacceptable form, in the laicist republics of Continental Europe. The Council, in contrast, accepting and prolonging the views of Pius XII and of John XXIII, makes a political commitment, however discreet, to constitutional government-or, if you will, to the juridical state-whose basic inspiration is a consciousness of the dignity of the person and a recognition of human rights. Only under this manner of government is the freedom of the 
Church, together with the freedom of man himself, assured. Hence the Council utters one of its few rebukes: "Disapproval is voiced of (reprobantur) those forms of government, to be found in some countries, which fetter civil and religious freedom ..." (n. 73). And again: "It is inhuman that political authority should assume totalitarian or dictatorial forms which do injury to the rights of the person or of associations" (n. 75).

To the transcendence of the Church are linked both the universality of her mission and her freedom in its accomplishment. However, transcendence to the world does not mean isolation from the world. The second major concern of the Constitution is to make this clear. The Council espouses the thesis of St. Augustine, developed in his treatise De civitate Dei, which Leo XIII had summed up in the opening paragraph of Immortale Dei and thereafter had endlessly repeated: "That immortal work of a merciful God, which is the Church, does indeed, per se and of its very nature, look to the salvation of souls and to their achievement of happiness in heaven. Nevertheless, in the world of mortal man it is the source of so many and such great benefits that it could not have brought forth more or greater benefits if it had been instituted, primarily and chiefly, to further the prosperity of life here on earth." 10 This is the traditional paradox.

The Constitution points to the resolution of it in the notion of the Church as "the leaven and, as it were, the soul of human society, which is to be renewed in Christ and transformed into the family of God." The relationship between the two Cities is described by the word "compenetration." And it is forthrightly stated that this dynamic relationship "can be perceived only by faith; it is, in fact, the mystery of human history" (n. 40).

At least the structure of the mystery can be described in these terms: "In pursuit of her salvific purpose, the Church communicates the divine life to men - but not only that; a reflection of her light somehow streams forth over the whole world, and its effect is chiefly shown in that it heals and elevates the dignity of the human person, strengthens the bonds of human society, and invests the daily activity of man with a deeper meaning and import" (n. 40). The terms are Augustinian and Leonine, but with a difference. The theme of human dignity has now

${ }^{10}$ Encyclical Immortale Dei, Nov. 1, 1885 (Bonne Presse 2, 16). 
become central in a new way: "By no human law can the personal dignity and freedom of man be so adequately safeguarded as by the gospel of Christ committed to the Church" (n. 41). Or again: "In virtue of the gospel committed to her, the Church proclaims the rights of man; she also acknowledges and holds in high regard the dynamism of today, whereby these rights are everywhere promoted" (loc. cit.).

There is more than a hint of triumphalism in the first part of this last sentence, though it is qualified by the second part. It would be fair to say that the Church - that is, the hierarchy and the Holy See-did nothing to advance the struggle for the political rights of man in the eighteenth and nineteenth centuries - those rights, notably the right of free speech, which safeguard the person against the encroachments of the state and also secure for citizens a share in the processes of government. Only rather late - with Rerum novarum in 1891-did the papacy enter the battle for the socio-economic rights of man. And it was not until Vatican II, of course, that the Church proclaimed the right to religious freedom. The victories won in the West for the cause of constitutional government and the rights of man owed little to the Church, however much the "leaven of the gospel," as Dignitatis inmanae insinuates (n. 12), may have contributed to the rise of the secular dynamism which, in fact, brought the "free world" into existence.

In any event, the statements in Gaudium et spes, like those in Dignilatis humanae, represent aggiornamento. And they are programmatic for the future. From now on, the Church defines her mission in the temporal order in terms of the realization of human dignity, the promotion of the rights of man, the growth of the human family towards unity, and the sanctification of the secular activities of this world.

This mission in the temporal order, however, still remains a mission of the religious order - a spiritual mission. It is limited in its scope as it is limited in the means of its accomplishment. These are entirely of the spiritual order: "The power which the Church is able to impart to human society today consists in faith and love made operative in life. It does not consist in any sort of external control exercised by merely human means" (n. 42). Here, of course, would be the place to outline the doctrine of the Decree on the Apostolate of the Laity, Apostolicam 
actuositatem, on the laity as the proper agent for the accomplishment of the mission of the Church in the temporal order. However, a mere reference to this doctrine must here suffice.

The discourse of Gaudium et spes on the life of the political community (Part 2, chapter 4) is uninspired and inadequate. For instance, there is no mention of the cardinal political principle of the consent of the governed, which is as old as Aristotle and Cicero, and which was central to the political thought of the High Middle Ages, even though the institutions to make it operative were lacking at that time. So too the section on the political community and the Church (n. 76) does no more than state a few general principles. At that, these are stated in such a way as to exhibit nuances of development.

Mention is made of the "pluralist society" (an almost last-minute addition to the text). It is suggested that this type of society gives rise to today's problem of the relations of Church and state. There is, however, no firm affirmation that the pluralist society presents not only the normal but also the normative context for any theory of these relations. The wider state of the question, "religion and government," which was implicitly adopted by Dignitatis humanae, is here contracted to the dimensions exhibited in the introductory rubric, "the political community and the Church." The narrowness of this view was probably necessary, but it was also regrettable.

The first assertion, here as earlier, bears on the transcendence of the Church to the political community and its various forms. The earlier idea of "compenetration" also appears, if only implicitly, in the statement that the Church "is at the same time the sign and safeguard of the transcendence of the human person" (n. 76). It is characteristic of Gaudium et spes that it occasionally strikes off a brilliant phrase, pregnant with implications, in the midst of a passage of otherwise prolix and uninspired prose. This is such a phrase. Its implications are extensive. It suggests the central significance of the Church for the political order. It suggests the locus standi of the Church in the face of the state - the order of public law and administration. It suggests the essential basis of the Church's claim to freedom in the face of all public powers. It implies that the Church may neither be enclosed within the political order nor be denied her own mode of spiritual entrance into the political order. It indirectly asserts the rightful 
secularity of the secular order, at the same time that it asserts the necessary openness of the secular order to the transcendent values whose pursuit is proper to the human person. If one were looking for a single phrase in which to resolve the whole problematic of Gaudium et spes-the dynamic relation of the Church to the world-this might well be the phrase, especially if it were understood that for the Church to signify and safeguard the transcendence of the human person is for her likewise to signify and further the unity of the human family.

The text does not fully draw out all these implications. It goes on briefly to reaffirm the Leonine principle: "The political community and the Church are independent of each other, and are autonomous, each in its own field" (n. 76). It further proceeds to reaffirm the principle, likewise Leonine, of their necessary harmony - except that it uses the word "co-operation" instead of the favorite Leonine word "concord." There is, however, an interesting nuance in the statement of the necessity for this concord or co-operation. For Leo, the reason lay in the fact that the two structures of authority, for all their independence as structures, held command and rule over the same body of menthe same one man who is "at once citizen and Christian." As Libertas puts it: "Utriusque est in eosdem imperium."'11 For Leo XIII, authority is rule. For the Council, however, authority is service: "Both [authorities], though on a different title, stand in the service of the personal and social vocation of the same men" (n. 76). This restatement of the Leonine doctrine reflects the more personalist conception, to call it such, both of the People of God and of the People Temporal.

The principle of co-operation of Church and state in the service of the human person is thus stated as a principle. However, the concrete forms of co-operation are to be instituted "under regard for circumstances of place and time" (n. 76). Implicit, here again, is a rejection of the disjunctive theory and its assertion of an abstract "thesis." Explicit is a recognition that the contingent relativities of history, and not any logical deductions from abstract principle, must determine the institutional forms of Church-state co-operation. Moreover, the rest of the paragraph makes it clear that the co-operation, both as a matter of principle and in the various forms of its realization, is not required by some sort of raison d'église but by the dual nature of the human

"Encyclical Libertas praestantissimum, June 20, 1888 (Bonne Presse 2, 192). 
person: "Man is not confined to the temporal order alone; rather, living his life in human history, he has a care for his eternal vocation in its wholeness" (n. 76).

Therefore, it is implied, the care of the Church extends in diverse ways to both aspects of man's destiny, since man is a unity and his destiny is somehow unitary. However, the limitations of the mission of the Church in the temporal order are again stated and all manner of clericalism is again rejected by this assertion: "Those who give themselves to the ministry of the word of God must make use of ways and means which are proper to the gospel; and these differ in many respects from the means at the disposal of the earthly city" (n. 76).

Finally, the Constitution comes to the principle of the freedom of the Church:

It is always and everywhere necessary that [the Church] should preach the faith with true freedom, teach her doctrine about society, exercise her function among men without hindrance, and pass moral judgment even on affairs that belong to the political order, when such judgment is required by concern for the fundamental rights of the person or for the salvation of souls, under use of all those means, and only those means, which are in harmony with the gospel and with the good of all, having regard for diversities of time and place (n. 76).

This statement of what the freedom of the Church means is not as extensive and complete as the statement made in Dignitatis humanae. However, in accord with its own context, it lays emphasis on the point less emphatically made in Dignitatis humanae, namely, the Church's freedom of spiritual entrance into the order of politics. The mode of entrance is purely spiritual, since it takes the form simply of moral judgment on political affairs, and since the grounds of judgment are metapolitical, having to do with the rights of man and the salvation of souls. Moreover, nothing is here said about the execution of these moral judgments in terms of law, public policy, social action, etc. On this crucial point the Constitution is content to have recalled a necessary distinction, "between those affairs which Christians, whether alone or in association, undertake as citizens, under the guidance of their Christian conscience, and those affairs which Christians undertake in the name of the Church and in union with their pastors" (n. 76). This distinction, one may think, is rather distinctively European in its origin and import. It began to come into currency in the twenties, 
under Pius XI, when there began to be talk of Catholic Action (with the initial letters in upper case), which is a form of organized apostolate not common outside the Latin countries.

In the context of discourse both about the evangelical character of the Church's resources and about the freedom of the Church, the Constitution makes a further important point, both of principle and of practice: "The Church does not put her trust in privileges granted by civil authority. More than that, she will renounce the exercise of certain legitimately acquired rights, when it shall have become clear that their exercise may call into question the disinterested character of her witness, or when new circumstances of life require different arrangements" (n. 76). The implicit disavowal of the ancient recourse to the secular arm is clear enough. The notion that certain rights of the Church can be merely historic-therefore contingently legitimate but not exigencies of doctrine-is likewise clear enough. But the privileges in question are not specified. Perhaps it may be permissible to see a reference to the modern right to legal establishment asserted within the nation-state, and to other consequent legal privileges. Thus the doctrine of Dignitatis humanae would be fittingly completed.

In any event, the sharpened awareness of the purely spiritual character of the Church's mission, even in the temporal order, which is visible all through the Constitution, leads necessarily to a new disposition on the part of the Church to impose self-denying ordinances on the whole range of her action within the temporal order. This new disposition is part of that spirit of evangelical poverty about which the conciliar Fathers frequently discoursed.

It is in place here to cite the invitation issued by Christus dominus to civil authorities that they should likewise pass some self-denying ordinances:

Consequently, in order rightly to protect the freedom of the Church and more fittingly and effectively to promote the good of the faithful, the Council desires that in the future no rights or privileges regarding the choice, nomination, presentation, or designation for the episcopal office should be granted to civil authorities. Moreover, civil authorities themselves, whose obedient disposition toward the Church the Council gratefully acknowledges, are courteously asked to renounce, of their own accord and after consultation with the Holy See, rights of this kind which they presently enjoy by compact or custom (n. 20). 
The premise of this request was the stated doctrine that "the right of nominating and installing bishops is the proper, peculiar, and per se exclusive right of competent ecclesiastical authority" (loc. cit.).

The tendency of the request itself is to realize more perfectly the implications of the principle stated by Leo XIII: "It cannot be doubted, under safeguard of the faith, that the governance of souls was committed to the Church alone, in such wise that powers of the political order have no share whatever in it." 12 The historic privilege of governments to nominate bishops was, however remotely and subtly, a share in the governance of souls. It was always per se an abuse, a confusion of the secular and sacral orders, and, as the Council clearly implied, an infringement of the freedom of the Church, an invasion of her immunity from political interference in all that concerns her own internal government and her care of souls.

The simple conclusion here is that the two conciliar documents, Dignitatis humanae and Gaudium et spes, have made a joint contribution toward the renewal of traditional doctrine with regard to the ancient issue of Church and state. Previous confusions of the historical with the doctrinal have been sorted out. The systematization based on the distinction between thesis and hypothesis has been dismantled. The relevant principles have been stated with a new purity, which was made possible by the new perspectives in which the whole issue was viewed. New theological insights into the concrete reality of the pilgrim Church, and other new insights made available by secular experience (notably the experience of the relation between religious freedom as a human right and the freedom of the Church), have resulted in genuine and fruitful development of doctrine. This doctrinal work was inspired by the maxim of Leo XIII, "Vetera novis augere et perficere." A work of systematization remains to be done under the same inspiration.

${ }^{12}$ Encyclical Sapientiae christianae, Jan. 10, 1890 (Bonne Presse 2, 283). 